\title{
TANDA DAN GEJALA GASTROPATI NSAID
}

\author{
Vaanipriya Gajapathi Rao \\ ${ }^{1}$ Program Studi Pendidikan Dokter, Fakultas Kedokteran Universitas Udayana
} (vaantamil1991@gmail.com)

ABSTRAK

Pendahuluan:Gastritis adalah proses inflamasi pada lapisan mukosa dan submukosa lambung dan secara histopatologi dapat dibuktikan dengan adanya infiltrasi sel- sel radang pada daerah tersebut. NSAID digunakan untuk mengobati reumatoid artritis, osteoartritis atau nyeri. NSAID merusak mukosa lambung melalui 2 mekanisme yaitu topikal dan sistemik. Kerusakan mukosa secara tropikal terjadi karena NSAID bersifat asam dan lipofili, sehingga mempermudah trapping ion hidrogen masuk mukosa dan menimbulkan kerusakan. Efek sistemik NSAID lebih penting yaitu kerusakan mukosa terjadi akibat produksi prostaglandin menurun secara bermakna.

Kasus:Pasien laki-laki, berumur 68 tahun, suku Bali, beragama Hindu datang pada 7 Januari 2015 dengan keluhan nyeri pada ulu hati sejak lama yaitu sekitar 6 bulan yang lalu dan memberat sejak \pm 2 hari yang lalu. Nyeri terasa seperti ditusuk-tusuk benda tumpul dan tidak menjalar, dirasakan pasien sepanjang hari. Nyeri awalnya muncul mendadak, dirasakan semakin memberat sampai mengganggu aktivitas sehari-hari pasien. Rasa nyeri ini tidak berkurang setelah pasien makan dan dengan obat. Pasien juga mengeluh nyeri yang ia rasakan semakin lama semakin bertambah terutama saat malam hari.

Kata Kunci: Gastritis, NSAID, gastropati

\section{ABSTRACT}

Introduction: gastritis is the process of inflammatory in the stomach mucous lining and submucous and in histopathology can be evidenced by the infiltration cells of the area. NSAID used to treat rheumatoid arthritis, osteoartritis or pain. NSAID damage gastric mucous through two mechanism that is topical and systemic. Mucous damage in topikal occurred because NSAID are acidic and lipophilic, making it easier trapping hydrogen ions enter the mucosa and cause damage. Systemic effects of NSAIDs are more important that mucosal damage caused by prostaglandin production decreases significantly.

Case: The patient was male, 68 years old, the tribe of Bali, a Hindu came on January 7, 2015 with complaints of pain in the gut for a long time which is about 6 months ago and was advancing from \pm 2 days ago. Pain feels like a tingling blunt and does not spread, the patient felt throughout the day. Pain initially appears suddenly, felt increasingly become heavy to interfere with the patient's daily activities. The pain did not diminish after patients eat and with drugs. Patients also complained of pain he felt increasingly growing, especially at night.

Keywords: Gastritis, NSAIDs, gastropathy

\section{PENDAHULUAN}

Gastritis adalah proses inflamasi pada lapisan mukosa dan submukosa lambung dan secara histopatologi dapat dibuktikan dengan adanya infiltrasi sel- sel radang pada daerah tersebut. ${ }^{1}$ Penyakit ini sering terjadi. Sekitar empat juta penduduk Amerika Serikat mengalami gangguan asam lambung dengan tingkat mortalitas sekitar 15.000 orang per tahun. ${ }^{2}$ Angka kejadian gastritis dari hasil penelitian yang dilakukan Kementrian Kesehatan Republik Indonesia tercatat, Jakarta mencapai 50\%, Denpasar 46\%, Palembang 35,3\%, Bandung 32,5\%, Aceh 31,7\%, dan Pontianak 31,2\%. Pada tahun 2009 tercatat 30.154 penderita gastritis 
yang mengalami rawat inap di rumah sakit di Indonesia, yang terdiri dari 12.378 orang adalah lakilaki dan 17.396 orang perempuan. ${ }^{1,2}$

Gastritis terjadi akibat ketidakseimbangan antara faktor penyebab iritasi lambung atau disebut juga faktor agresif seperti $\mathrm{HCl}$, pepsin, dan faktor pertahanan lambung atau faktor defensif yaitu adanya mukus bikarbonat. ${ }^{3} \quad$ Penyebab ketidakseimbangan faktor agresif- defensif antara lain adanya infeksi Helicobacter pylori (H.pylori) yang merupakan penyebab yang paling sering (30$60 \%$ ), penggunaan obat-obatan yaitu obat golongan Antiinflamasi Non-Steroid (NSAID), kortikosteroid, obat-obat anti tuberkulosa serta pola hidup dengan tingkat stres tinggi, minum alkohol, kopi, dan merokok. ${ }^{1,4,5,7}$

NSAID digunakan untuk mengobati reumatoid artritis, osteoartritis atau nyeri. Berbagai jenis NSAID dapat menghambat sintesis prostaglandin (PG) yang merupakan mediator inflamasi dan mengakibatkan berkurangnya tanda inflamasi. $^{1} \quad$ Akan tetapi, PG khususnya PGE sebenarnya merupakan zat yang bersifat protektor untuk mukosa saluran cerna atas. Hambatan sintesis PG akan mengurangi ketahanan mukosa, dengan efek berupa lesi akut mukosa gaster bentuk ringan sampai berat. $^{3}$

NSAID merusak mukosa lambung melalui 2 mekanisme yaitu topikal dan sistemik. Kerusakan mukosa secara tropikal terjadi karena NSAID bersifat asam dan lipofili, sehingga mempermudah trapping ion hidrogen masuk mukosa dan menimbulkan kerusakan. ${ }^{8}$ Efek sistemik NSAID lebih penting yaitu kerusakan mukosa terjadi akibat produksi prostaglandin menurun secara bermakna., ${ }^{6,8}$ Seperti diketahui prostaglandin merupakan substansi sitoprotektif yang amat penting bagi mukosa lambung. Efek sitoproteksi itu dilakukan dengan cara menjaga aliran darah mukosa, meningkatkan sekresi mukosa dan ion bikarbonat dan meningkakan epitel defensif. ${ }^{1}$ la memperkuat sawar mukosa lambung duodenum dengan meningkatkan kadar fosfolipid mukosa sehingga meningkatkan hidrofobisitas permukaan mukosa, dengan demikian mengurangi difusi balik ion hidrogen. ${ }^{9}$
Manifestasi klinis bervariasi dari tanpa gejala, gejala ringan dengan manifestasi tersering dispepsia, heartburn, abdominal discomfort, dan nausea; hingga gejala berat seperti tukak peptik, perdarahan dan perforasi. Keluhan lain yang biasa dirasakan pasien adalah mengalami gangguan pada saluran pencernaan atas, berupa nafsu makan menurun, perut kembung dan perasaan penuh di perut, mual, muntah dan bersendawa. Jika telah terjadi pendarahan aktif dapat bermanifestasi hematemesis dan melena. ${ }^{6,7,8}$

Diagnosis gastropati NSAID dapat ditegakkan berdasarkan anamnesis, pemeriksaan fisik, pemeriksaan penunjang. Pada anamnesis dapat ditemukan gejala gastrointestinal seperti dispepsia, heartburn, abdominal discomfort, dan nausea nafsu makan menurun, perut kembung dan perasaan penuh di perut, mual, muntah dan bersendawa. Pada pemeriksaan fisik dapat ditemukan nyeri tekan pada daerah epigastrium dan dapat ditemukan distensi abdomen pada gejala yang berat. ${ }^{6,8}$

Untuk pemeriksaan penunjang dapat dilakukan pemeriksaan EGD (Esofagogastroduedenoscopy) dan pemeriksaan histopatologi. Pada EGD dapat dijumpai kongesti mukosa, erosi-erosi kecil dan kadang-kadang disertai pendarahan kecil. Lesi seperi ini dapat sembuh sendiri. ${ }^{7,8}$ Lesi yang lebih berat dapat berupa erosi dan tukak multiple, pendarahan luas dan perforasi saluran cerna.

Penanganan perlukaan mukosa karena NSAID terdiri dari penanganan terhadap ulkus aktif dan pencegahan primer terhadap perlukaan di kemudian hari. Idealnya, NSAID dihentikan sebagai langkah pertama terapi ulkus. Selanjutnya, pada penderita diberikan obat penghambat sekresi asam (penghambat H2, PPIs). Akan tetapi, penghentian NSAID tidak selalu memungkinkan karena beratnya penyakit yang mendasari. Penggunaan protein pump inhibitor (PPI) berhubungan dengan penyembuhan ulkus dan mencegah relaps pada penderita yang menggunakan NSAID jangka panjang. ${ }^{10}$

Untuk pencegahan ulkus primer dapat digunakan misoprostol (4 kali $200 \mu \mathrm{g}$ per hari) atau PPI. Dalam studi aplikasi mukosa misoprostol $200 \mathrm{mg}$ 4 kali sehari terbukti mengurangi tingkat 
keseluruhan komplikasi NSAID sekitar 40\%. Namun, penggunaan misoprostol dosis tinggi dibatasi karena efek samping terhadap GI. Selain itu, penggunaan misoprostol tidak berhubungan dengan pengurangan gejala dyspepsia. $8,9,11$

Penghambat $\mathrm{H} 2$ dosis tinggi (famotidine 2 kali $40 \mathrm{mg}$ per hari) dapat dianjurkan sebagai pengganti PPI walaupun PPI seperti omeprazole dan pantoprazole lebih superior.

Selain mengurangi paparan asam pada epitel yang rusak dengan membentuk gel pelindung (sucralfate) atau dengan netralisasi asam lambung (antasida). Efek samping sucralfat yang paling banyak terjadi yaitu konstipasi.Preparat antasida yang paling banyak digunakan adalah campuran dari alumunium hidroksida dengan magnesium hidroksida. Efek samping yang sering terjadi adalah konstipasi dan diare..$^{8,9}$

Dengan struktur serupa dengan histamin, antagonis reseptor $\mathrm{H} 2$ tersedia dalam empat macam obat yaitu simetidin, ranitidin, famotidin, dan nizatidin. Dua kali sehari dengan dosis standard dapat menurunkan angka kejadian ulkus gaster. Selain itu, antagonis reseptor $\mathrm{H} 2$ dapat menurunkan risiko tukak duodenum tetapi perlindungan terhadap tukak lambung rendah. Dosis malam yang sesuai adalah ranitidin $300 \mathrm{mg}$, famotidin $40 \mathrm{mg}$ dan nizatidin $300 \mathrm{mg} .6,7,8$

Proton pump inhibitors merupakan pilihan komedikasi untuk mencegah gastropati NSAID. Obat ini efektif untuk penyembuhan ulkus melalui mekanisme penghambatan $\mathrm{HCl}$, menghambat pengasaman fagolisosom dari aktivasi neutrofil, dan melindungi sel epitel serta endotel dari stres oksidatif melalui induksi haem oxygenase-1 (HO-1). Enzim HO-1 adalah enzim pelindung jaringan dengan fungsi vasodilatasi, anti inflamasi, dan antioksidan. Waktu paruh PPIs adalah 18 jam dan dibutuhkan 2-5 hari untuk menormalkan kembali sekresi asam lambung setelah pemberian obat dihentikan. ${ }^{6,9}$ Efikasi maksimal didapatkan pada pemberian sebelum makan. Obat PPI menyebabkan pengurangan gejala klinis dispepsia karena NSAID dibanding antagonis reseptor $\mathrm{H} 2$ maupun misoprostol. Lansoprazol dan misoprostol dosis penuh. secara klinis menunjukkan efek ekuivalen.
Esomeprazole 20 dan $40 \mathrm{mg}$ meredakan gejala gastrointestinal bagian atas pada penderita yang tetap menggunakan NSAID. ${ }^{9,10,11}$

\section{KASUS}

Pasien laki-laki, berumur 68 tahun, suku Bali, beragama Hindu datang pada 7 Januari 2015 dengan keluhan nyeri pada ulu hati sejak lama yaitu sekitar 6 bulan yang lalu dan memberat sejak \pm 2 hari yang lalu. Nyeri terasa seperti ditusuk-tusuk benda tumpul dan tidak menjalar, dirasakan pasien sepanjang hari. Nyeri awalnya muncul mendadak, dirasakan semakin memberat sampai mengganggu aktivitas sehari-hari pasien. Rasa nyeri ini tidak berkurang setelah pasien makan dan dengan obat. Pasien juga mengeluh nyeri yang ia rasakan semakin lama semakin bertambah terutama saat malam hari. Pasien juga mengeluhkan bahwa dirinya merasakan lebih lemas dibandingkan hari-hari sebelumnya. Rasa lemas dirasakan sejak nyeri ulu hati muncul. Rasa lemas dikatakan membuat aktivitas pasien sedikit terganggu. BAB pasien dikatakan belum sejak 2 hari sebelum MRS. Dikatakan pasien dapat BAK pada pagi harinya dengan volume $\pm 200 \mathrm{ml}$. Makan dan minum pasien dikatakan berkurang sejak saat nyeri ulu hati dirasakan. Pasien juga mengeluh adanya nyeri pada lutut kiri, hilang timbul sejak \pm 6 bulan yang lalu dan memberat sejak 1 hari SMRS. Nyeri dirasakan hilang timbul dan memberat pada pagi hari. Nyeri dirasakan hingga mengganggu aktivitas. Keluhan demam, mual, muntah dan nyeri menelan disangkal oleh pasien.

Pasien sempat berobat sejak keluhan muncul pertama kali, namun gejala tetap ada walaupun sudah minum obat. Pasien lupa nama obat yang diberikan saat itu.

Sebelumnya pada bulan September 2014 pasien sempat dirawat d RSUP Sanglah selama 10 hari. Saat itu pasien merasakan nyeri pada ulu hatinya bertambah berat sehingga pasien dibawa ke rumah sakit oleh keluarganya. Selain itu, pasien juga mengeluh adanya nyeri pada lutut kiri, hilang timbul sejak \pm 6 bulan yang lalu dan mendapat pengobatan untuk keluhan nyeri pada lutut kirinya. Nyeri dirasakan hilang timbul dan memberat pada pagi hari. Nyeri dirasakan hingga mengganggu aktivitas. 
Keluhan demam, mual dan muntah disangkal. Pasien mendapatkan terapi Antasida syr 3xCl, Omeprazole $1 \times 20 m g$ dan Sucralfat syr $3 x \mathrm{Cl}$ untuk keluhan nyeri ulu hatinya. Untuk keluhan di lutut kirinya pasien mendapatkan terapi paracetamol 3x750mg, Allupurinol 1x100mg dan Kolkisin 2x0,5mg. Pasien juga sebelumnya juga dirawat di RSUP Sanglah dengan penyakit ginjal.

Tidak ada keluarga pasien yang memiliki keluhan yang sama. Riwayat tekanan darah tinggi ada. Riwayat kencing manis, asma, alergi obat, penyakit jantung, hati, dan ginjal pada keluarga disangkal.

Pasien mengaku tidak memiliki jadwal teratur untuk makan dan sering terlambat makan. Riwayat merokok disangkal oleh pasien. Pasien mengatakan bahwa ia hanya minum-minuman beralkohol jika ada acara adat di banjar saja. Pasien mengatakan sering mengkonsumsi jamu-jamuan sejak dikeluhkan nyeri pada lututnya karena dikatakan keluhan pasien berkurang setelah meminum jamu.

Pada pemeriksaan tekanan darah, nadi, laju nafas dan suhu didapatkan normal. Pada pemeriksaan generalis ditemukan anemis pada mata, dan nyeri tekan abdomen pada epigastrium.

Pada pemeriksaan laboratorium darah lengkap pada 5 Januari 2015 didapatkan hasil RBC $2,98 \times 10^{6} \mu \mathrm{L} ; 8,70 \mathrm{~g} / \mathrm{dL}$; dan hematokrit 27,30\% yang termasuk kategori rendah. Kategori tinggi pada hasil laboratorium kimia darah dengan BUN 38,08 $\mathrm{mg} / \mathrm{dL}$ dan creatinin $2,5 \mathrm{mg} / \mathrm{dL}$. Pada analisa gas darah didapatkan hasil $\mathrm{pH}$ 7,33 dan kadar $\mathrm{HCO}_{3}$ 19,5 (rendah)

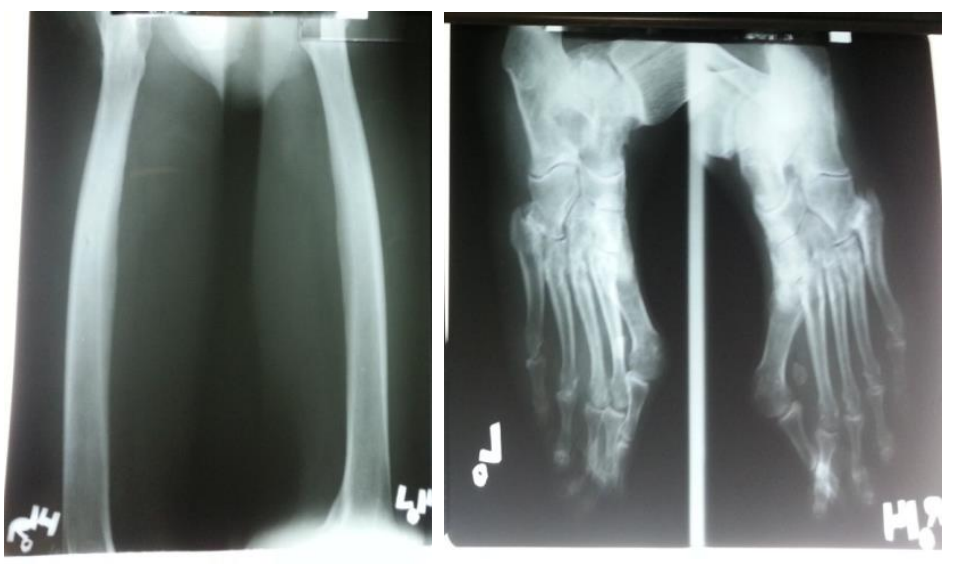

Gambar 1. Foto Rontgen Femur Kanan Kiri AP/Lateral/ Pedis Kanan Kiri AP/Oblique (6 Januari 2015)

Pernah dilakukan foto rontgen dengan hasil sesuai gambar dengan kesan gambaran rheumatoid arthritis pedis kiri dan kanan.

Pasien didiagnosis dengan gastropati NSAID, CKD stage IV et causa PNC dengan anemia ringan dan asidosis metabolik, serta Rhematoid Arthritis FC III.

Pasien ditata laksana dengan rawat inap, diet makan lunak dan rendah purin, IVFD RL 20 tetes/menit, Pantoprazole 2 x $40 \mathrm{mg}$ IV, Antasida sirup $3 \times \mathrm{Cl}$, Sucralfat sirup $3 \times \mathrm{Cl}$, Asam folat $1 \times 5 \mathrm{mg} /$ minggu, Paracetamol $3 \times 1000 \mathrm{mg}$ apabila nyeri lutut, MTX 1 x $75 \mathrm{mg} /$ minggu. Dengan monitoring tanda-tanda vital dan keluhan lain.

\section{DISKUSI}

Gastropati NSAID adalah gejala gastropati yang mengacu kepada spektrum komplikasi saluran cerna bagian atas yang dihubungkan oleh penggunaan obat anti inflamasi non steroid dengan durasi waktu tertentu, dan biasanya disebabkan oleh penggunaan jangka panjang NSAID. ${ }^{1,5}$ Pada kasus ditemukan gambaran komplikasi saluran cerna seperti nyeri pada daerah epigastrium yang dimana keluhan tersebut dirasakan sejak mengkonsumsi 
obat NSAID untuk pengobatan keluhan nyeri lutut yang dilakukan penderita. Gambaran kasus ini cocok dengan definisi gastropati NSAID.

Spektrum penggunaan NSAID yang menginduksi gastropati bervariasi yaitu mulai dari mual dan dispepsia (prevalensi yang dilaporkan 50\%$60 \%$ sampai dengan komplikasi gastrointestinal yaitu ulserasi peptikum (3\%-4\%), diikuti dengan perdarahan atau perforasi sebanyak 1,5\% dari pengguna setiap tahun. Hampir 20.000 pasien meninggal setiap tahun akibat komplikasi gastrointestinal yang serius dari pemakaian NSAID. Pada kasus didapatkan keluhan dyspepsia yang merupakan prevalensi yang paling tinggi untuk keluhan pada gastropati NSAID. Pada pasien tidak ditemukan baik ulserasi maupun perforasi gaster sebagai komplikasi gastropati NSAID.

Resiko untuk mendapatkan efek samping NSAID tidak sama untuk semua orang. Faktor-faktor resiko yang penting adalah usia lanjut lebih dari 60 tahun, digunakan bersama-sama dengan steroid, riwayat pernah mengalami efek samping NSAID, dosis tinggi atau kombinasi lebih dari satu macam NSAID dan disabilitas. Pada pasien ini terdapat faktor resiko yaitu usia lanjut lebih dari 60 tahun (68 tahun) dan riwayat pernah mengalami efek samping NSAID sehingga pasien ini dikategorikan sebagai pasien dengan factor resiko sedang untuk mendapatkan efek samping gastrointestinal dari penggunaan NSAID.

Manifestasi klinis bervariasi dari tanpa gejala, gejala ringan dengan manifestasi tersering dispepsia, heartburn, abdominal discomfort, dan nausea; hingga gejala berat seperti tukak peptik, perdarahan dan perforasi. Keluhan lain yang biasa dirasakan pasien adalah mengalami gangguan pada saluran pencernaan atas, berupa nafsu makan menurun, perut kembung dan perasaan penuh di perut, mual, muntah dan bersendawa. Jika telah terjadi pendarahan aktif dapat bermanifestasi hematemesis dan melena. ${ }^{6,7,8}$ Pada kasus ditemukan manifestasi klinis dyspepsia, nyeri ulu hati dan penurunan nafsu makan. Untuk keluhan mual, muntah, tukak peptic, hematemesis, melena dan perforasi gaster tidak ditemukan pada pasien ini.
Diagnosis gastropati NSAID dapat ditegakkan berdasarkan anamnesis, pemeriksaan fisik, pemeriksaan penunjang. Pada anamnesis pasien ini ditemukan keluhan utama berupa nyeri ulu hati sejak lama yaitu sekitar 6 bulan yang lalu dan memberat sejak \pm 2 hari yang lalu. Nyeri terasa seperti ditusuk-tusuk benda tumpul dan tidak menjalar, dirasakan pasien sepanjang hari. Nyeri awalnya muncul mendadak, dirasakan semakin memberat sampai mengganggu aktivitas sehari-hari pasien. Rasa nyeri ini tidak berkurang setelah pasien makan dan dengan obat. Pasien juga mengeluh nyeri yang ia rasakan semakin lama semakin bertambah terutama saat malam hari. Pasien juga mengeluhkan bahwa dirinya merasakan lebih lemas dibandingkan hari-hari sebelumnya. Rasa lemas dirasakan sejak nyeri ulu hati muncul. Rasa lemas dikatakan membuat aktivitas pasien sedikit terganggu. BAB pasien dikatakan belum sejak 2 hari sebelum MRS. Rasa lemas disini dapatdikarenakan anemia yang diderita pasien dan dapat sebagai akibat dari nafsu makan pasien yang menurun. Pasien juga memiliki riwayat mengkonsumsi NSAID yaitu kolkisin untuk keluhan nyeri lutut kirinya. Selain itu ditemukan riwayat mengkonsumsi jamu-jamuan sejak nyeri lutut kiri dirasakan.

Pada pemeriksaan fisik pasien ditemukan gambaran anemia pada pemriksaan mata dan nyeri tekan pada daerah epigastrium. Untuk pemeriksaan penunjang Darah lengkap ditemukan Anemia Normokromik Normositer. Anemia ini dapat disebabkan oleh gangguan fungsi ginjal yang dialami pasien dimana kita ketahui bahwa ginjal memegang peranan penting dalam produksi eritropoetin. Tidak ditemukan peningkatan WBC pada Darah Lengkap hal ini mengindikasikan kecil kemungkinan adanya proses infeksi. Pada pemeriksaan Kimia Klinik didapatkan BUN dan SC yang meningkat menandakan bahwa terdapat gangguan fungsi ginjal. Untuk Analisis Gas Darah terdapat PH darah yang relatif rendah dan terdapat penurunan ion bikarbonat yang menandakan terjadi asidosis metabolik. Hal ini cocok dengan keadaan pasien dimana penurunan fungsi ginjal akan mengakibatkan penurunan produksi ion bikarbonat dimana kita ketahui ion bikarbonat adalah ion yang penting 
dalam keseimbangan asam basa. Pada pemeriksaan EGD ditemukan gambaran hiperemis pada daerah antrum yang memberikan gejala nyeri epigastrium pada pasien ini. Dari anamnesis dan pemeriksaan penunjang pasien ini cocok untuk memberikan diagnosis kerja sebagai Gastropati NSAID.

NSAID dihentikan sebagai langkah pertama terapi ulkus. Pada pasien dengan riwayat penggunaan NSAID yang mempunyai keluhan gastrointestinal dan pada EGD tidak ditemukan ulser maka langkah yang diambil adalah dengan memberikan agen gastroproktetif. Penghambat $\mathrm{H} 2$ dosis tinggi (famotidine 2 kali $40 \mathrm{mg}$ per hari) dapat dianjurkan sebagai pengganti PPI walaupun PPI seperti omeprazole dan pantoprazole lebih superior.Selain mengurangi paparan asam pada epitel yang rusak dengan membentuk gel pelindung (sucralfate) atau dengan netralisasi asam lambung (antasida), kedua regimen telah ditunjukkan untuk mendorong berbagai mekanisme gastroprotektif. Pada pasien ini diberikan Pantoprazole 2 x $40 \mathrm{mg}$ IV, Antasida syr $3 x \mathrm{Cl}$ dan Sucralfat syr $3 x \mathrm{Cl}$ sebagai gastroprotektif.

Jika tidak tertangani dengan baik, komplikasi gastropati OAINS dapat muncul pada penderita. Komplikasi tersebut meliputi perdarahan gastrointestinal (hematemesis, melena), perforasi, striktura, syok hipovolemik, dan kematian. Pada pasien ini dapat tertangani dengan baik sehingga tidak mengarah ke komplikasi serius untuk gastropati NSAID.

\section{DAFTAR PUSTAKA}

1. Pedoman Diagnosis dan Terapi Ilmu penyakit Dalam. Bagian/SMF IImu Penyakit Dalam Fakultas Kedokteran Universitas Udayana/RSUP Sanglah. Denpasar. 2013.

2. Suyata, Bustami E, Bardiman S, Bakry F. A comparison of efficacy between rebamipide and omeprazole in the treatment of nsaids gastropathy. The Indonesian Journal of Gastroenterology Hepatology and Digestive Endoscopy Vol. 5, No. 3, December 2004; p.89-94.

3. Tugushi M. Nonsteroidal anti inflamatory drug (NSAID) associated gastropathies [online]. World Medicine [cited January 28 2011]. Available from: http://www.worldmedicine.ge/?Lang=2\&le vel1=5\&event=publication \&id=39

4. Hirlan. Gastritis. In: Sudoyo AW, Setiyohadi B, Alwi I, Simadibrata M, Setiati S (editor). Buku Ajar IImu Penyakit Dalam, Ed.4 Jilid.I. Jakarta: Pusat Penerbitan IImu Penyakit Dalam FKUI. 2006. p.335-7.

5. Scheiman JM. Nonsteroidal antiinflamatory drug (NSAID)-induced gastropathy. In: Kim, Karen (editor). Acute gastrointestinal bleeding; diagnosis and treatment. New Jersey: Humana Press Inc. 2004. p.75-93

6. Becker JC, Domschke W, Pohie T. Current approaches to prevent NSAID-induced gastropathy - COX selectivity and beyond. Br J Clin Pharmacol 58 :6.2004; p.587-600

7. Lindseth GN. Gangguan lambung dan duodenum. In: Price SA, Wilson LM (editors). Patofisiologi: konsep klinis prosesproses penyakit Ed.6 Vol.1. Jakarta: Penerbit ECG. 2002. p.417-35.

8. Tarigan P. Tukak Gaster. In: Sudoyo AW, Setiyohadi B, Alwi I, Simadibrata M, Setiati S (editor). Buku Ajar Ilmu Penyakit Dalam, Ed.4 Jilid.I. Jakarta: Pusat Penerbitan IImu Penyakit Dalam FKUI. 2006. p.338-48.

9. Anonim. Kerusakan lambung akibat NSAID. Otuska Indonesia [online]. 2008 [cited January 28 2011]. Available from: http://www.otsuka.co.id/?content=article detail\&id=144\&lang=id

10. Shrestha S, Lau D. Gastric Ulcers: differential diagnose \& workup. Emedicine [online]. 2009 [cited January 28 2011]. Available from: http://emedicine.medscape.com/article/17 5765-overview

11. Almatsier $\mathrm{S}$ (editor). Diet penyakit lambung. In: Penuntun diet edisi baru. Jakarta: Gramedia Pustaka Utama. 2007. p.108-16. 